International Journal of Health Sciences
Available online at www.sciencescholar.us
Vol. 5 No. 3, December 2021, pages: $573-583$
e-ISSN: 2550-696X, p-ISSN: $2550-6978$
https://doi.org/10.53730/ijhs.v5n3.2490

\title{
Academic Mobility Development among University Students during COVID-19 Pandemic
}

Valentyna Slipchuk ${ }^{\text {a }}$, Halyna Yuzkiv ${ }^{b}$, Nina Batechko ${ }^{c}$, Maryna Pisotska ${ }^{d}$, Liudmyla Klymenko e

Manuscript submitted: 26 July 2021, Manuscript revised: 18 October 2021, Accepted for publication: 22 November 2021

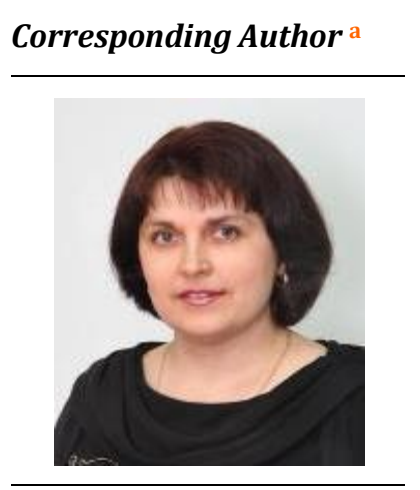

Keywords

academic career;

academic mobility;

COVID-19;

health services;

higher education;

socialization;

\begin{abstract}
The aim of the article is to study the academic mobility of students in the context of internationalization of education, exchange of experiences and gaining additional knowledge and skills between participants in the process of academic mobility. The research methodology is to use methods of questionnaires, surveys, interviews among students to study the prospects, advantages, disadvantages and opportunities of academic mobility. The results of the study cover the internal and external mobility of university students and provide an opportunity to assess the dynamics of quantitative indicators of international mobility. Factors influencing the academic mobility of students and graduate students are identified. The types of academic mobility that are the most common among university students are identified and the importance of academic mobility for the success of student learning and future career development is clarified. The internationalization of higher education stimulates the quality of education, the diversity of education, and the free exchange of educational resources. This, in turn, generates opportunities for students to experience a "global village" along with an appreciation for other cultures - one of the many "hidden" benefits.
\end{abstract}

International Journal of Health Sciences (C) 2021. This is an open access article under the CC BY-NC-ND license (https://creativecommons.org/licenses/by-nc-nd/4.0/).

\section{Contents}

Abstract

1 Introduction..

2 Materials and Methods.

3 Results and Discussions

a Bogomolets National Medical University, Kyiv, Ukraine

b Bogomolets National Medical University, Kyiv, Ukraine

c National University of Life and Environmental Sciences of Ukraine, Kyiv, Ukraine

d Skovoroda Kharkiv National Pedagogical University, Kharkiv Oblast, Ukraine

e National University of Life and Environmental Sciences of Ukraine, Kyiv, Ukraine 


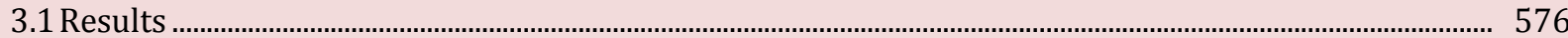

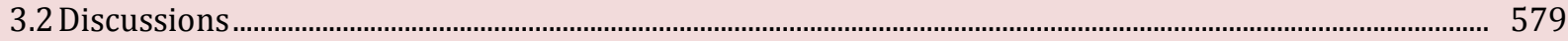

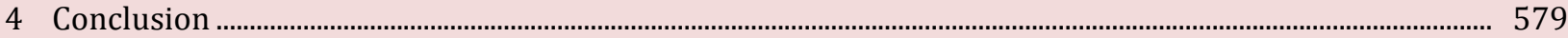

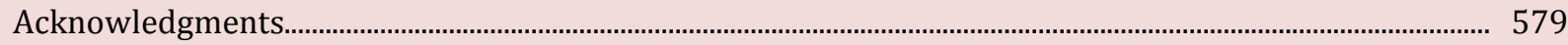

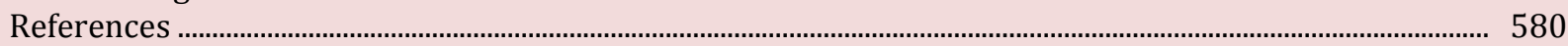

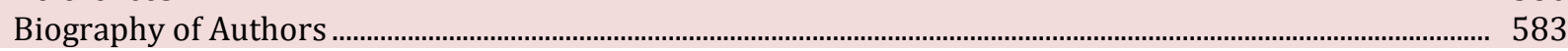

\section{Introduction}

The current stage in the development of educational systems is characterized by the significant influence of globalization and internationalization of higher education, as well as the creation of a common information space during the COVID-19 pandemic. On the one hand, a common European space leads to the acceleration of student and faculty mobility, on the other hand, academic mobility shapes this space (Danilyuk \& Paschenko, 2012). Taking into account these trends, the strategic goal of the state education policy is to promote academic mobility, which directly increases the chances of professional growth of individuals, in addition to improving the quality of human resources involved in the national economy.

Now education during the COVID-19 pandemic is seen as one of the most important values, without which the further development of intellectual capital is impossible on a global level. In modern economic globalization, high educational potential guarantees the inclusion of the country in the world economy as a competitive player. The greatest role in this process is played by university education, which provides training of highly mobile personnel and forms the basis for the entry of national intellectual capital in the global learning environment. In this context, academic mobility is an important tool for shaping the global educational space and human capital mobility, improving the quality, efficiency, and accessibility of higher education (Seidahmetov et al., 2014).

The relevance of the topic of this article is confirmed by the fact that the rights of students on academic mobility are enshrined at the European and national levels. In particular, one of the requirements of the communiqué of the Ministerial Conference of the European Union, which was held in Belgium on April 28-29, 2009 , aimed at deepening the international openness of European higher education and increasing to 20\% of the share of 2020 graduates who studied or did an internship abroad (Roblyer et al., 2010). Moreover, during the Bucharest conference, held April 26-28, 2012, the ministers of the participating countries of the Bologna Process, including Ukraine, signed the communique "Harnessing potential to the greatest advantage: consolidation of higher education in Europe", which declared the intention to balance mobility across Europe (Georgina \& Olson, 2008). Despite considerable academic mobility, little research has been conducted on academic mobility topics and even less on the role of language in the increasingly diverse community of educational institutions.

\section{Literature review}

The only view in the literature is that internationalization is a sign of the relationship between universities and therefore is not a recent phenomenon, although it has intensified on the world stage since the 1990s with the acceleration of the process (Pretty et al., 2003; Skorobogatova, 2016). Academic mobility and exchange are not new, but they have also long contributed to the internationalization of higher education (Altbach, 2002). The global transition of higher education has been characterized by increasing flows of institutions, programs, students, and scholars, as well as changing relationships between universities, governments, and the marketplace (Pretty et al., 1996; Ryazantsev et al., 2019). There are more than 2,5 million international students worldwide, and it is estimated that this number will reach 70 million by 2020 (Chen, 2017). Student mobility has been widely discussed as part of the internationalization of higher education processes by many authors (Knight \& Woldegiorgis, 2017; Teichler, 2004). Academic mobility has become frequent and has even been seen as "a kind of professional standard in some disciplines" because it helps dissipate the formal and informal rules that prevail in other countries.

Internationally mobile students have been defined by Kelo, Teichler, and Wachter as "students who cross national borders for the purpose or context of their studies" (Kelo et al., 2006). Regarding the types of 
academic mobility, student mobility can be either internal or moving students from one country to another or between regions of the world or within a region. Conceptualizing student mobility in higher education has been difficult, as the movement of students across national borders has sometimes been confused with other concepts such as migration and brain drain. However, the length of time international students stay in the host country can be seen as a determining factor for understanding and using student mobility-related terms (Iontsev et al., 2016; Pretty et al., 1994). Accordingly, student mobility can be for short periods, such as in "exchange programs", or it can be for the entire program as "study abroad. Thus, international student mobility can be characterized as students crossing borders and staying in another country to receive shortterm or long-term training in higher education or within a region, within a region, or between countries in different regions between regions (Woldegiorgis \& Doevenspeck, 2015).

Mobility is now seen as a central feature of academic careers by research institutions, policymakers, and individual researchers (Daniels et al., 2017; Khalafallah et al., 2020). It is usually discussed positively, both at the political and individual levels. Frequently considered as the "fifth freedom" in the EU (along with the movement of people, capital, goods, and services), academic mobility is seen as one of the prerequisites for building competitive science and thus for building knowledge and innovation-driven economy (Blachford \& Zhang, 2014; Day \& Stilgoe, 2009).

On an individual level, academic mobility is associated with professional development, competence development, and "broadening one's horizons" (Day \& Stilgoe, 2009; Ackers, 2009). In many fields, mobility has become a prerequisite for a successful start to an academic career and career advancement. This tendency has gradually begun to spread from the natural and technical sciences to the social sciences and humanities (Cervinkova, 2010; Attamimi et al., 2020).

For higher education institutions, high levels of student mobility are a sign of prestige and quality (Green, 2012; Wildavsky, 2010), not least because internationalization is now an important indicator in world rankings (Hazelkorn, 2015). Many countries have already successfully implemented many programs to facilitate academic mobility, including programs such as Erasmus Mundus, DAAD, Tempus Fulbright Program, etc. (Bogoslovsky, 2017; Martynenko, 2017).

In the European Union (EU), the home degree mobility of international students has grown steadily in recent years (Vossensteyn, 2010). Erasmus is the most student exchange program for higher education in Europe and the leading EU program. Souto-Otero, Huisman, Beerkens, de Wit, and Vujić highlighted the barriers higher education students face in studying abroad (Souto-Otero, 2013). The majority of research has been done on the problems and barriers faced by those students who go abroad, not the problems of those who do not (Findlayet al., 2010; Pietro \& Page, 2008; Otero et al., 2006).

The importance of knowing the barriers faced by students who choose not to participate is important, as it has been found that the importance of these barriers varies from country to country (Vossensteyn, 2010). Furthermore, there are important differences in participation by field of study, specifically, it is a social science, business, and law degrees that have a higher percentage of mobility compared to science and health services, according to 2013-14 data would have ranked 4th (Fajó-Pascual et al., 2017).

A sense of where we live is often related to our sense of personal identity because, in many ways, we are dependent on where we live and the experiences we had there (Relph, 1976; Proshansky et al., 1983). Thus, people tend to develop very strong sentimental and emotional attachments to the places where they spend their lives (Shumaker, 1983). This attachment is also called "place identification" (Proshansky et al., 1983), this term describes the relationship between people and places, emphasizing the role of place in shaping one's sense of identity. Sentiments of attachment and community identity grow with years of living (Chavis et al., 1986; Prezza et al., 2001), and change at different periods of life. The overall conclusion is that people who have lived in the community longer tend to have higher rates of attachment and place identity (Rubinstein \& Parmelee, 1992; Mahardika et al., 2021).

\section{Materials and Methods}

The Moscow State University of Food Production, as one of the most prestigious and reputable institutions of higher education in the Russian Federation, was chosen to conduct the study. The results of the implementation of the outbound academic mobility program based on the information were provided on the

Slipchuk, V., Yuzkiv, H., Batechko, N., Pisotska, M., \& Klymenko, L. (2021). Academic mobility development among university students during COVID-19 pandemic. International Journal of Health Sciences, 5(3), 573-583.

https://doi.org/10.53730/ijhs.v5n3.2490 
website of the Ministry of Education of the Russian Federation. The academic mobility programs are the main forms of educational mobility in the university. Information about academic mobility was presented on the university website, but it was obvious that not all students were familiar with this information (Ginsburgh et al., 2007; Osipov et al., 2015; Widana et al., 2021). For first-year students, this information was new, while older students were already fully or partially familiar with it. Some students were native students, born in Moscow or the surrounding area, other students came from different parts of Russia and, so far, lived in Moscow during the period of study. The place identity was assessed using material developed by Pretty, Chipuer, and Bramston. A confirmation was used to identify the identity of the home place.

A total of 291 students at Moscow State University of Nutrition were interviewed, 183 of whom were undergraduate students ( 111 female, 72 male) and 108 students enrolled in the master's program ( 50 female, 58 male). The areas of training for the students are related to food technology and service. All students agreed to answer the questions voluntarily and anonymously. Participants were asked to answer a question about their age, gender, course of study, and year at the university, without giving their last names:

1) Please provide information about yourself:

- Are you a student in an undergraduate program, years 1, 2, 3, 4 (please underline)?

- Are you a student of the Master's degree program, years 1, 2 (please underline)?

- Gender - male, female (please underline)

- Whether Moscow is your native city? Yes, No (please underline)

- Do you live on campus?

2) Do you know about academic mobility programs?

3) Are you interested in a short-term foreign language program (language course)?

4) Are you interested in a short-term degree program (credit mobility program)?

5) Are you interested in a long-term specialty training program (full course)?

6) Do you know about the European Credit Transfer and Accumulation System - ECTS?

7) Do you think that your level of English will be important for studying abroad?

- Do you have an international certificate confirming the level of your English?

- What other languages besides English can you use effectively (i.e., fluently)?

8) Would you like to participate in an academic mobility program?

9) Please indicate which factors of studying abroad are important to you in making your decision concerning learning abroad. The level of the factor importance: 1 - not important at all, 2 - slightly important, 3 - mildly important, 4 - very important, 5 - extremely important. These elements were constructed based on a review of the literature and items from previous surveys.

10) Think about your native place of residence and indicate your agreement with the following statement: "I would rather live somewhere else. It's not the best place for me," using five levels of agreement on whether the statement is true: 1 = definitely not true; 2 = false; $3=$ undecided; $4=$ true; $5=$ very true. The research on the effect of gender on responses has not been conducted.

\section{Results and Discussions}

\subsection{Results}

The results of the survey are grouped according to the approved number of applications by country, participation in the forms of academic migration, and knowledge of foreign languages. Table 1 provides information that illustrates the dynamics of changes in the quantitative characteristics of international mobility. 
Table 1

The breakdown of the approved number of applications by country COVID-19 pandemic

\begin{tabular}{|c|c|c|c|c|c|}
\hline № & Country & $\begin{array}{l}\text { The participants } \\
\text { approved in } \\
2014\end{array}$ & $\begin{array}{l}\text { The participants } \\
\text { approved in } \\
2015\end{array}$ & $\begin{array}{l}\text { The participants } \\
\text { approved in } \\
2016\end{array}$ & $\begin{array}{l}\text { The total } \\
\text { number }\end{array}$ \\
\hline 1 & China & 129 & 141 & 175 & 445 \\
\hline 2 & Hungary & 7 & 8 & 103 & 118 \\
\hline 3 & Serbia & 23 & 31 & 27 & 81 \\
\hline 4 & Czech Republic & 11 & 22 & 45 & 78 \\
\hline 5 & Norway & 25 & 13 & 34 & 72 \\
\hline 6 & Slovakia & 12 & 30 & 30 & 72 \\
\hline 7 & Vietnam & 12 & 18 & 22 & 52 \\
\hline 8 & Romania & 13 & 16 & 18 & 47 \\
\hline 9 & Italy & 16 & 13 & 16 & 45 \\
\hline 10 & Bulgaria & 15 & 13 & 11 & 39 \\
\hline 11 & Denmark & 14 & 12 & 8 & 34 \\
\hline 12 & Belgium & 11 & 6 & 6 & 23 \\
\hline 13 & Mongolia & 6 & 3 & 14 & 23 \\
\hline 14 & Austria & 3 & 5 & 6 & 14 \\
\hline 15 & France & 3 & 3 & 6 & 12 \\
\hline 16 & Turkey & 0 & 10 & 0 & 10 \\
\hline 17 & Kuwait & 2 & 3 & 4 & 9 \\
\hline 18 & Poland & 3 & 0 & 0 & 3 \\
\hline 19 & Brunei & 0 & 1 & 1 & 2 \\
\hline 20 & Mexico & 0 & 1 & 0 & 1 \\
\hline 21 & Slovenia & 0 & 1 & 0 & 1 \\
\hline
\end{tabular}

Source: http://im.interphysica.su/

Table 2 reflects the students' attitude towards various forms of participation in educational mobility programs.

Table 2

The participation in forms of academic mobility (it was possible to mark more than one point)

\begin{tabular}{lcccc}
\hline & $\begin{array}{c}\text { Bachelor's } \\
\text { program } \\
\text { students, 1-2 } \\
\text { years of study, \% }\end{array}$ & $\begin{array}{c}\text { Bachelor's } \\
\text { program } \\
\text { students, 3-4 } \\
\text { years of study, \% }\end{array}$ & $\begin{array}{c}\text { Master's } \\
\text { program } \\
\text { students, 1-2 } \\
\text { years of study, \% }\end{array}$ & $\begin{array}{c}\text { Master's } \\
\text { program } \\
\text { students, 3-4 } \\
\text { years of study, \% }\end{array}$ \\
\hline $\begin{array}{l}\text { Number of students } \\
\text { interested in a short-term } \\
\text { foreign language course }\end{array}$ & 33 & & & \\
$\begin{array}{l}\text { Number of students } \\
\text { interested in short-term }\end{array}$ & & 15 & 16 & 11 \\
$\begin{array}{l}\text { mobility credit program (up } \\
\text { to 1 year) }\end{array}$ & 54 & & & \\
$\begin{array}{l}\text { Number of students } \\
\text { interested in the full-range } \\
\text { course }\end{array}$ & & 43 & 31 & 22 \\
$\begin{array}{l}\text { Number of students aware of } \\
\text { ECTS }\end{array}$ & 32 & & & \\
Number of students & 4 & 47 & 53 & 22 \\
\hline
\end{tabular}

Slipchuk, V., Yuzkiv, H., Batechko, N., Pisotska, M., \& Klymenko, L. (2021). Academic mobility development among university students during COVID-19 pandemic. International Journal of Health Sciences, 5(3), 573-583. https://doi.org/10.53730/ijhs.v5n3.2490 
considering participation in

the program

Table 3

The answers of Bachelor's and Master's students about their knowledge of foreign languages (Do you think your level of English language proficiency will be sufficient for studying abroad?)

\begin{tabular}{|c|c|c|}
\hline Language & $\begin{array}{l}\text { Students of the Bachelor's degree program, } \\
\% / \text { Number of students with international } \\
\text { certificate }\end{array}$ & $\begin{array}{c}\text { Students of the Master's degree program, } \\
\% / \text { Number of students with international } \\
\text { certificate }\end{array}$ \\
\hline English & $15 / 5$ & $22 / 3$ \\
\hline German & $6 / 1$ & 6/- \\
\hline French & $3 /-$ & $2 /-$ \\
\hline Italian & $2 /-$ & $1 /-$ \\
\hline
\end{tabular}

Table 1 shows the different countries that offer different numbers of places for Russian students. This table shows the distribution of the quantitative indicators of international exchanges by country. China leads by a large margin (175 internships), Hungary comes second (103 approved internships). The next 6 places are occupied by the rest of Europe (136 internships). The third place in the Czech Republic (45 internships), the fourth is Norway (34 internships), the fifth is Slovakia (29 internships + one continuation), sixth is Serbia (27 internships). The total for European countries - 312 internships. In the European countries of the former socialist camp, there were 236 internships.

According to the Ministry of Education, the largest competition - in France (4.75), in Italy (3.38), Austria (2.8), Belgium (2.17), Norway (1.87). Only two former socialist European countries had more than 1 person per seat competition: Slovakia (1.88) and Serbia (1.2). A separate situation with China: the highest number of applications (158) and competition - 1.22 people per seat. The last 4 places are divided as follows: Mongolia (0.25), Hungary (0.24), Vietnam (0.22), Poland (0.08), all former socialist countries. Thus, we can conclude that cooperation programs are mainly offered by the countries of the former communist bloc at the same time as social needs apply to internships in Western European countries. In China, there is a completely separate situation: here there is a combination of a large number of places offered and applications (McLeod, 2000; Singh-Manoux \& Marmot, 2005).

The internationalization of higher education is a political objective of the governments of the respective countries. It stimulates the quality of education, the diversity of education, and the free exchange of educational resources. This, in turn, generates opportunities for students to experience a "global village" along with an appreciation for other cultures - one of the many "hidden" benefits (Education, 2017).

As with higher education, scholarly work also undergoes a process of internationalization. It is facilitated by the creation of regional research clusters and international competition for research funding (Ningsih et al., 2021). For effective implementation of plans for scientific integration of the global community, a significant factor is the existence of conditions for the implementation and development of academic mobility. After all, it becomes possible to create a common scientific space and use educational resources (Gromov, 2016). Table 2 results show that short-term language courses are more popular with undergraduate students in the 1st and 2nd-year programs (33\%).

Short-term credit mobility (up to a year) attracts more undergraduate program students than master's program students (54\% and $43 \%$ ). This type of mobility is popular because it allows students to continue their studies at their home institution while also participating in the academic mobility program (Hussin et al., 2021). The students noted that short-term programs (3 months to a year) are more interesting. Such programs are offered by foreign universities, sometimes the period of study varies from one term to one year. The latter is true for master's programs at foreign universities, which offer students to take a one-year educational program. The full course is less popular with first- and second-year undergraduate students. Usually, the first year is a very challenging time, and students are less willing to consider education abroad, especially for any educational program that requires a long time. 
These data show that students have very little information about the European Credit Transfer System (ECTS). The credit system is used in Russian universities, but very few students, especially in the first years of study, are aware of the purpose of the system. First-year students are less aware of it (14\%), while master's students have more information about it (42\%). Young people are interesting and want to take advantage of different opportunities in life. Table 3 shows the results of self-assessments of foreign language levels and expectations that the level would be relevant to study abroad. Most bachelor's and master's degree students indicated that they were proficient in English (15\% and 22\%), German (6\% and 6\%), French (3\% and 2\%), and Italian ( $2 \%$ and $1 \%)$. Very few students had an international certificate.

\subsection{Discussions}

This research finds that the process of internationalization of higher education is accelerating and expanding. Rapid economic developments and their direct dependence on the quality of the workforce are contributing to this. The requirement to study in a language other than English is becoming a major barrier (Lane-Toomey \& Lane, 2013). Sanchez, Fornerino, and Zhang suggest that students had barriers to study abroad such as: familial, financial, psychological (related to aspects such as feeling for students of their own country and fear of new places), and social (related to friends and family) - although they felt this to varying degrees (Sanchez et al., 2016).

The current research confirms the barriers that participants face in academic mobility, which depend on their level of social success and psychological adaptability. A huge number of students (86\% of survey participants) found their interest in educational mobility programs. And their interest remains relatively high throughout their studies. Many global problems, such as climate change and epidemic diseases, require global solutions. Therefore, scientists from all over the world are increasing their cooperation, trying to try to create a knowledge-based society.

The growth in the number of students worldwide is the main trend of higher education in recent decades, which has proven to be a public good. In the $1970 \mathrm{~s}$, there were 28.5 million students in the three-tiered education system worldwide, about $62 \%$ of whom were male. By 2000 , the number of students had risen to 100 million. Since the beginning of the XXI century, education worldwide has experienced a marked period of growth in popularity in its history. By 2005, the number of students had risen to 139 million people, by 2010 to 181 million people, and in 2012 there were already 196 million students. The UNESCO Institute for Statistics predicts that in 2025 the number of students in the three-tiered education system will increase up to 263 million people (Education, 2016).

\section{Conclusion}

The definition of academic mobility has been completed over time. Academic mobility is generally perceived and discussed as a positive phenomenon - a prerequisite for building a competitive and successful economy and quality science during the COVID-19 pandemic. Academic mobility has now become an important part of a successful academic career in many academic fields. In this research, it is important to consider the aspects that influence students' decision whether or not to participate in an educational program abroad. The lack of information, the uncertainty of participants in this process at the level of English that would be relevant for academic purposes, and the need to know the language of the host country are the main reasons holding back the development of international educational cooperation in this field. To increase participation, the focus should be on improving information about international programs and the various facets of education abroad. Taking into account the continuous development of academic mobility and its importance for national economies, further research on this topic is relevant and promising, both for scholars and for state governments.

Acknowledgments

We are grateful to two anonymous reviewers for their valuable comments on the earlier version of this paper.

Slipchuk, V., Yuzkiv, H., Batechko, N., Pisotska, M., \& Klymenko, L. (2021). Academic mobility development among university students during COVID-19 pandemic. International Journal of Health Sciences, 5(3), 573-583.

https://doi.org/10.53730/ijhs.v5n3.2490 


\section{References}

Ackers, L., \& Gill, B. (2009). Moving people and knowledge: Scientific mobility in an enlarging European Union. Edward Elgar Publishing.

Altbach, P. (2002). Perspectives on internationalizing higher education. International Higher Education, (27).

Attamimi, H. R. ., Lestari, Y. ., Situmorang, B. . H. L. ., Antari, G. Y. ., \& Nugrawati, N. . (2020). Application of habituation method in germas interventionsin: the pandemic time COVID-19. International Journal of Health \& Medical Sciences, 3(1), 98-104.

Blachford, D. R., \& Zhang, B. (2014). Rethinking international migration of human capital and brain circulation: The case of Chinese-Canadian academics. Journal of Studies in International Education, 18(3), 202-222.

Bogoslovsky V. (2017). Razvitie akademicheskoj mobil'nosti v mnogourovnevom universitetskom obrazovanii: metod rekomendacii dlya prepodavatelej [Development of academic mobility in multi-level university education: a recommendation method for teachers], St. Petersburg, Herzen State Pedagogical University.

Červinková, A. (2010). „Postdokovat po světě “: genderové politiky akademické mobility. Gender rovné př́ležitosti výzkum, 11(01), 49-59.

Chavis, D. M., Hogge, J. H., McMillan, D. W., \& Wandersman, A. (1986). Sense of community through Brunswik's lens: A first look. Journal of community psychology, 14(1), 24-40.

Chen, Q. (2017). Higher education transition and academic mobility in China. In Globalization and Transnational Academic Mobility (pp. 13-31). Springer, Singapore.

Daniels, M., Garzon-Muvdi, T., Maxwell, R., Tamargo, R. J., Huang, J., Witham, T., ... \& Chaichana, K. L. (2017). Preresidency publication number does not predict academic career placement in neurosurgery. World neurosurgery, 101, 350-356. https://doi.org/10.1016/j.wneu.2017.02.028

Danilyuk, I., \& Paschenko, S. (2012). Academic mobility and professionalism of higher school staff in ukraine: evaluation and assessment. Procedia-Social and Behavioral Sciences, 69, 1785-1794. https://doi.org/10.1016/j.sbspro.2012.12.128

Day, N., \& Stilgoe, J. (2009). Knowledge nomads: why science needs migration. London: Demos.

Fajó-Pascual, M., Gómez, E. M., Vercet, A., Molina, A., Ferrer-Mairal, A. M., Sanclemente, T., ... \& Poblador, J. A. (2017). Obstáculos para la movilidad académica con el programa Erasmust: Diferencias entre grados universitarios [Barriers to academic mobility with Erasmust programme: Differences between bachelor degrees] (No. COMPON-2017-0102).

Findlay, A. M., King, R., Geddes, A., Smith, F., Stam, A., Dunne, M., ... \& Ahrens, J. (2010). Motivations and experiences of UK students studying abroad.

Georgina, D. A., \& Olson, M. R. (2008). Integration of technology in higher education: A review of faculty selfperceptions. The Internet and Higher Education, 11(1), 1-8. https://doi.org/10.1016/j.iheduc.2007.11.002

Ginsburgh, V., Ortuño-Ortín, I., \& Weber, S. (2007). Learning foreign languages: Theoretical and empirical implications of the Selten and Pool model. Journal of Economic Behavior \& Organization, 64(3-4), 337-347. https://doi.org/10.1016/j.jebo.2006.10.005

Green, M. F. (2012). Measuring and assessing internationalization. NAFSA: Association of International Educators, 1, 1-26.

Gromov, A. D. (2016). Akademicheskaja mobil'nost'inostrannyh studentov v Rossii [Academic mobility of foreign students in Russia]. Education Facts, 7, 1-15.

Hazelkorn, E. (2015). Rankings and the reshaping of higher education: The battle for world-class excellence. Springer.

Hussin, D. A., Samah, M. A. A., Suhaimi, A. A., \& Kamarudin, M. K. A. (2021). A study on knowledge, attitude and practice of COVID-19 pandemic among the residents. International Journal of Health Sciences, 5(2), 177188. https://doi.org/10.29332/ijhs.v5n2.1378

Iontsev, V. A., Ryazantsev, S. V., \& Iontseva, S. V. (2016). Emigration from Russia: new trends and forms. $R$ Economy, 2(2), 216-224.

Kelo, M., Teichler, U., \& Wächter, B. (2006). Toward improved data on student mobility in Europe: Findings and concepts of the Eurodata study. Journal of Studies in International Education, 10(3), 194-223.

Khalafallah, A. M., Jimenez, A. E., Daniels, M., Bydon, A., Cohen, A. R., Tamargo, R. J., ... \& Mukherjee, D. (2020). Educational program rankings are independently associated with residents' academic career trajectory in 


$\begin{array}{lllll}\text { neurological } & \text { surgery. Journal } & \text { of } & \text { surgical } & \text { education, } 77(5), 1320 .\end{array}$
https://doi.org/10.1016/j.jsurg.2020.03.004

Knight, J., \& Woldegiorgis, E. T. (Eds.). (2017). Regionalization of African higher education: Progress and prospects. Springer.

Lane-Toomey, C. K., \& Lane, S. R. (2013). US students study abroad in the Middle East/North Africa: Factors influencing growing numbers. Journal of Studies in International Education, 17(4), 308-331.

Mahardika, I. M. R., Suyasa, I. G. P. D., Kamaryati, N. P., \& Wulandari, S. K. (2021). Health literacy is strongest determinant on self-monitoring blood glucose (SMBG) type 2 DM patients during COVID-19 pandemic at public health centre in Tabanan Regency. International Journal of Health \& Medical Sciences, 4(3), 288-297.

Martynenko 0. 0. (2017). Otchet po proektu «Obobshchenie opyta uchastiya vuzov Rossijskoj Federacii v realizacii principov Bolonskogo processa» [Report on the project Summarizing the experience of participation of universities of the Russian Federation in the implementation of the principles of the Bologna process], Vladivostok.

McLeod, J. M. (2000). Media and civic socialization of youth. Journal of Adolescent Health, 27(2), 45-51. https://doi.org/10.1016/S1054-139X(00)00131-2

Ningsih, S., Ismail, D., \& Indriani, I. (2021). Study protocol: relationship between parenting patterns and diet with nutritional status of toddlers during COVID-19 pandemic. International Journal of Health Sciences, 5(2), 128-134. https://doi.org/10.29332/ijhs.v5n2.1336

Osipov, I. V., Prasikova, A. Y., \& Volinsky, A. A. (2015). Participant behavior and content of the online foreign languages learning and teaching platform. Computers in Human Behavior, 50, 476-488. https://doi.org/10.1016/j.chb.2015.04.028

Otero, M. S., McCoshan, A., \& Ecotec Research and Consulting. (2006). Survey of the Socio-Economic Background of ERASMUS Students DG EAC 01/05. Ecotec.

Pietro, G. D., \& Page, L. (2008). Who studies abroad? Evidence from France and Italy. European Journal of Education, 43(3), 389-398.

Pretty, G. H., Chipuer, H. M., \& Bramston, P. (2003). Sense of place amongst adolescents and adults in two rural Australian towns: The discriminating features of place attachment, sense of community and place dependence in relation to place identity. Journal of environmental psychology, 23(3), 273-287.

Pretty, G. M., Andrewes, L., \& Collett, C. (1994). Exploring adolescents' sense of community and its relationship to loneliness. Journal of community psychology, 22(4), 346-358.

Pretty, G. M., Conroy, C., Dugay, J., Fowler, K., \& Williams, D. (1996). Sense of community and its relevance to adolescents of all ages. Journal of community psychology, 24(4), 365-379.

Prezza, M., Amici, M., Roberti, T., \& Tedeschi, G. (2001). Sense of community referred to the whole town: Its relations with neighboring, loneliness, life satisfaction, and area of residence.Journal of community psychology, 29(1), 29-52.

Proshansky, H. M., Fabian, A. K., \& Kaminoff, R. (1983). Place-identity: Physical world socialization of the self. Journal of environmental psychology.

Relph, E. (1976). 1976: Place and placelessness. London: Pion.

Roblyer, M. D., McDaniel, M., Webb, M., Herman, J., \& Witty, J. V. (2010). Findings on Facebook in higher education: A comparison of college faculty and student uses and perceptions of social networking sites. The Internet and higher education, 13(3), 134-140. https://doi.org/10.1016/j.iheduc.2010.03.002

Rubinstein, R. I., \& Parmelee, P. A. (1992). Attachment to place and the representation of the life course by the elderly. In Place attachment (pp. 139-163). Springer, Boston, MA.

Ryazantsev, S. V., Rostovskaya, T. K., Skorobgatova, V. I., \& Bezverbny, V. A. (2019). International academic mobility in Russia: Trends, types, state stimulation. Ekonomika Regiona, (2), 420.

Sánchez, C. M., Fornerino, M., \& Zhang, M. (2006). Motivations and the intent to study abroad among US, French, and Chinese students. Journal of Teaching in International Business, 18(1), 27-52.

Seidahmetov, M., Kulanova, D., Abdikerimova, G., Myrkhalykova, A., \& Abishova, G. (2014). Problem Aspects of Academic Mobility are in Republic of Kazakhstan. Procedia-Social and Behavioral Sciences, 143, 482-486. https://doi.org/10.1016/j.sbspro.2014.07.523

Shumaker, S. A., \& Taylor, R. B. (1983). Toward a clarification of people-place relationships: A model of attachment to place. Environmental psychology: Directions and perspectives, 2, 19-25.

Slipchuk, V., Yuzkiv, H., Batechko, N., Pisotska, M., \& Klymenko, L. (2021). Academic mobility development among university students during COVID-19 pandemic. International Journal of Health Sciences, 5(3), 573-583.

https://doi.org/10.53730/ijhs.v5n3.2490 
Singh-Manoux, A., \& Marmot, M. (2005). Role of socialization in explaining social inequalities in health. Social science \& medicine, 60(9), 2129-2133. https://doi.org/10.1016/j.socscimed.2004.08.070

Skorobogatova, V. I. (2016). Spravedlivoe priznanie inostrannogo obrazovaniya: tendentsii, perspektivy [Fair recognition of foreign education: trends, prospects]. Gosudarstvennyy sovetnik [The state counsellor], 1, 4953.

Souto-Otero, M., Huisman, J., Beerkens, M., De Wit, H., \& Vujić, S. (2013). Barriers to international student mobility: Evidence from the Erasmus program. Educational researcher, 42(2), 70-77.

Teichler, U. (2004). Temporary study abroad: The life of ERASMUS students. European Journal of education, 39(4), 395-408.

Vossensteyn, H., Lanzendorf, U., \& Souto-Otero, M. (2010). Contributing to quality, openness and internationalisation-the Erasmus Impact Study 2008. In Higher Education Institutions in Europe: Mobilised by mobility? (pp. 15-23). University of Kassel.

Vossensteyn, J. J., Beerkens-Soo, M., Beerkens, M., Cremonini, L., Besançon, B., Focken, N., ... \& de Wit, H. (2010). Improving the participation in the ERASMUS programme.

Widana, I.K., Sumetri, N.W., Sutapa, I.K., Suryasa, W. (2021). Anthropometric measures for better cardiovascular and musculoskeletal health. Computer Applications in Engineering Education, 29(3), 550561. https://doi.org/10.1002/cae.22202

Wildavsky, B. (2010). The Great Brain Race: How Global Universities Are Reshaping the. World (Princeton, NJ: Princeton University Press, 2010).

Woldegiorgis, E. T., \& Doevenspeck, M. (2015). Current Trends, Challenges and Prospects of Student Mobility in the African Higher Education Landscape. International Journal of Higher Education, 4(2), 105-115. 


\section{Biography of Authors}

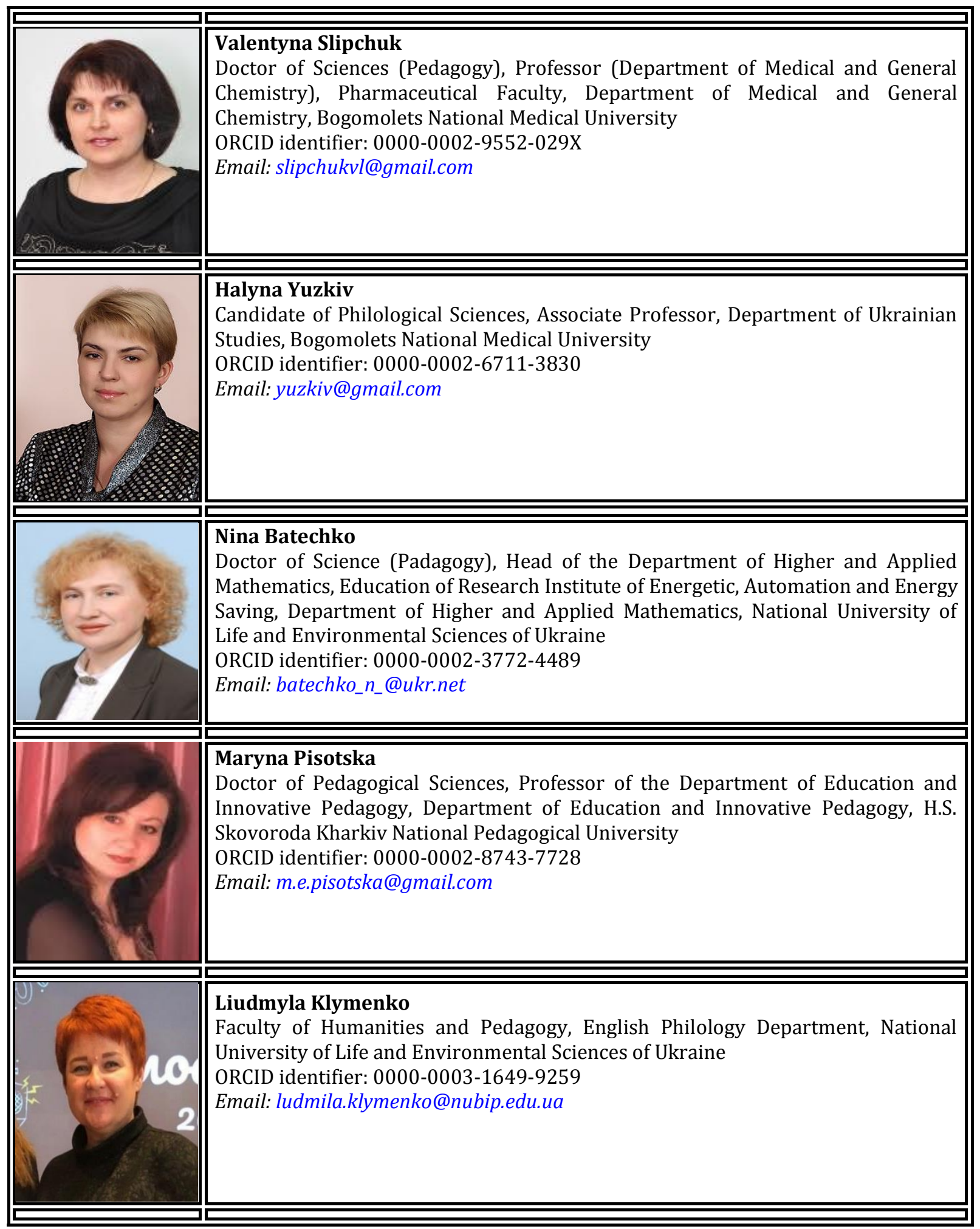

Slipchuk, V., Yuzkiv, H., Batechko, N., Pisotska, M., \& Klymenko, L. (2021). Academic mobility development among university students during COVID-19 pandemic. International Journal of Health Sciences, 5(3), 573-583. 